\title{
AKSI UKI PERDULI DALAM RANGKA PENCEGAHAN PENYEBARAN VIRUS COVID-19
}

\author{
Elferida Sormin ${ }^{1}$, Nelius Harefa ${ }^{2}$, Fransiska Sitompul ${ }^{3}$, Evy S.Arodes ${ }^{4}$, Jap Mai Cing ${ }^{5}$ \\ Aarce Tehupeiory ${ }^{6}$, Lamhot Naibaho ${ }^{7}$, Nova Irawati Simatupang ${ }^{8}$, Familia Novita \\ Simanjutntak $^{9}$, Leony Sanga Lamsari Purba ${ }^{10}$, Sumiyati ${ }^{11}$, St Fatimah Azzahra ${ }^{12}$ \\ 1,2,3,4,5,6,7,8,9,10,11,12Universitas Kristen Indonesia \\ Jalan Mayjen Sutoyo No 2 Cawang, Jakarta Timur \\ E-mail : elferida.sormin@uki.ac.id¹, nelius.harefa@uki.ac.id², \\ fransiska.sitompul@uki.ac.id ${ }^{3}$, evy.adores@uki.ac.id ${ }^{4}$, japmaicing@uki.ac.id ${ }^{5}$, \\ aatrje.tehupeiory@uki.ac.id ${ }^{6}$, lamhot.naibaho@uki.ac.id ${ }^{7}$, nova@uki.ac.id ${ }^{8}$, \\ familia.simanjuntak@uki.ac.id ${ }^{9}$, leony.purba@uki.ac.id ${ }^{10}$, sumiyati@uki.ac.id ${ }^{11}$, \\ fatimah.azzahra@uki.ac.id ${ }^{12}$
}

\begin{abstract}
Abstrak
Pandemi Covid-19 yang terjadi di seluruh dunia telah membuat perubahan dalam banyak hal di kehidupan masayarakat. Secara khusus di Indonesia, berita tentang maraknya penyebaran virus covid-19 mulai pada bulan Januari 2020 hingga akhirnya awal Maret pemerintah mengambil keputusan yang sangat sulit dengan mengeluarkan kebijakan Pembatasan Sosial Berskala Besar (PSBB), di mana berbagai sektor terkhusus di bidang pendidikan diharapkan melaksanakan seluruh kegiatan secara online. Tidak terkecuali Perguruan Tinggi Universitas Kristen Indonesia turut mematuhi kebijakan yang dikeluarkan oleh pemerintah. Adanya rasa ketakutan yang mendalam pada masyarakat yang mendorong untuk menjaga diri dengan menerapkan protokol kesehatan dan juga menjaga kebersihan dengan mencuci tangan atau menggunakan hand sanitizer membuat masyarakat secara khusus di Jakarta berlomba-lomba untuk memiliki antiseptik pencuci tangan karena dinilai efektif membunuh kuman atau virus. Sehingga persediaan antiseptik ini pun langka dan melambung tinggi. Kondisi ini menjadi perhatian Universitas Kristen Indonesia sebagai Perguruan Tinggi yang berkomitmen menjalankan Tri Dharma Perguruan Tinggi yang salah satunya adalah Pengabdian kepada Masyarakat dan juga oleh dorongan kemanusiaan membantu pemerintah pada masa-masa sulit di saat pandemi covid-19, sehingga Universitas Kristen Indonesia melalui karya pengabdian para dosen di Prodi Pendidikan Kimia FKIP dan Fakultas Kedokteran bersama-sama dengan Lembaga Penelitian dan Pengabdian kepada Masyarakat (LPPM) melaksanakan kegiatan "Aksi UKI Perduli Dalam Rangka Pncegahan Penyebaran Virus Covid-19". Dalam kegiatan PkM ini para dosen bekerja di laboratorium dengan mematuhi protokol kesehatan dalam rangka membuat atau memproduksi hand sanitizer sesuai dengan standar World Health Organization (WHO), dan selanjutnya mendistribusikan produk tersebut ke masyarakat melalui puskesmas-puskesmas dan kelurahan-kelurahan yang ada di Jakarta Timur. Sebanyak 2000 botol kemasan $100 \mathrm{~mL}$ hand sanitizer diproduksi dan didistribusikan oleh Universitas Kristen Indonesia melalui dua tahapan waktu.
\end{abstract}

Kata kunci: Pengabdian kepada Masyarakat; Aksi Perduli; Hand Sanitizer; Pandemi Covid-19 


\begin{abstract}
The Covid-19 pandemic that occurred around the world has made changes in many things in people's lives. In particular in Indonesia, news about the widespread spread of the Covid-19 virus starting in January 2020 until finally in early March the government made a very difficult decision by issuing a Large-Scale Social Restriction (PSBB) policy, in which various sectors especially in the education sector are expected to implement all online activities. The Indonesian Christian University Colleges are no exception to comply with policies issued by the government. There is a deep sense of fear in the community that encourages them to take care of themselves by implementing health protocols and also maintaining cleanliness by washing their hands or using hand sanitizers, making people especially in Jakarta compete to have handwashing antiseptics because they are considered effective in killing germs or viruses. So that this antiseptic supply is scarce and soaring. This condition is of concern to the Christian University of Indonesia as a tertiary institution that is committed to implementing the Tri Dharma of Higher Education, one of which is Community Service and also by humanitarian encouragement to help the government during difficult times during the Covid-19 pandemic, so that the Indonesian Christian University through community service works lecturers at the FKIP Chemistry Education Study Program and the Medical Faculty together with the Institute for Research and Community Service (LPPM) carried out the "UKI Cares Action in Preventing the Spread of the Covid-19 Virus". In this PkM activity, the lecturers work in the laboratory by complying with health protocols in order to make or produce hand sanitizers in accordance with World Health Organization (WHO) standards, and then distribute these products to the public through community health centers and sub-districts in East Jakarta. . A total of 2000 bottles of $100 \mathrm{~mL}$ hand sanitizer were produced and distributed by the Christian University of Indonesia in two stages.
\end{abstract}

Keywords: Community Service; Caring Action; Hand Sanitizer; The Covid-19 Pandemic 


\section{PENDAHULUAN}

Pandemi Covid-19 secara revolusi
telah mengakibatkan banyak
perubahan dalam berbagai aspek
kehidupan masyarakat secara global. Hampir seluruh sektor kegiatan masyarakat mendapatkan dampak dari pandemi yang mulai marak melanda mulai bulan Desember tahun 2019 ini. Bagaikan luapan banjir melanda semua wilayah yang dilewatinya, demikian pandemi covid-19 ini masuk dan membawa dampak ke sektor Kesehatan, Ekonomi, Industri, Perdagangan, Pertanian, Perikanan, Pertahanan Kemananan, Kesejahteraan bahkan Sosial Budaya masyarakat, terlebih lagi di bidang pendidikan

Proses penyebaran dari virus sangat cepat dari satu orang ke orang lain yang melakukan kontak fisik secara langsung. Setelah menyebarnya virus dan meningkatnya jumlah penderita corona, pemerintah Indonesia mengumumkan agar warga melakukan social distancing atau physical distancing (Mona, 2020). Physical distancing bisa diartikan dengan jaga jarak atau jaga jarak aman. Akibat diterapkannya physical distancing, kegiatan belajar-mengajar di sekolah maupun kampus telah berubah dari pembelajaran yang dilakukan secara tatap muka (langsung) menjadi pembelajaran jarak jauh (online) atau lebih dikenal dengan pembelajaran daring. Walaupun secara praktik kondisi ini sangat sulit, namun di baliknya terdapat beberapa dampak pembelajaran daring ini yakni meningkatkan kemamapuan berpikir kritis para peserta didik untuk dapat menyesuaikan diri dengan hal yang baru, termasuk di antarnya adalah penggunaan teknologi dalam pembelajaran. (Nadeak, B., 2020)

Kebijakan pembatasan Sosial Berskala Besar (PSBB) yang diambil oleh pemerintah di satu sisi adalah dengan tujuan memutus rantai penyebran virus covid-19, dalam pelaksanaan PSBB ini juga turut berimbas pada ruang gerak masyarakat dengan usia di atas 60 tahun yang dikenal dengan istilah lansia, di mana dalam kaitanyya dengan PSBB para Lansia tidak diperkenankan melakukan aktifitas di tempat umum, mengunjungi tempat hiburan dan wisata. Secara psikis tentu hal ini juga berpengaruh kepada emosi para Lansia, di mana seharusnya mereka turut diaktifkan dalam berbagai kegiatan utnuk menunjang produktifitas. (Sormin, E. 2019).

Menjaga kestabilan emosi dalam hal ini secara psikis menjadi hal yang sangat penting dilakukan dalam melewati masa pandemi covid-19 ini. Melaksanakan aktifitas dari rumah memberikan peluang untuk dapat memiliki waktu lebih banyak dengan keluarga, membina hubungan yang harmonis dalam keluarga dapat memberi semangat dan kemampuan dalam menghadapi berbagai ketakutan dan kekhawatiran. (Nadeak, B., 2020). Hubungan yang harmonis dan intim secara langsung dapat memberikan kondisi di mana akan terjalin komunikasi yang baik antara sesama anggota keluarga, sehingga hubungan antara ayah, ibu dan anak dapat tercipta yang secara langsung juga merupakan wadah pendidikan bagi anak. Karena pendidikan juga diawali dalam keluarga. (Nadeak, B., 2020), di mana pendidikan secara psikologisnya merupakan upaya memanusiakan 
manusia yang dapat dilakukan sejak dini dimulai dari keluarga dan lingkungan. (Arifudin, O., 2020).

Selain dapat mengelola emosi, hal yang sangat tidak kalah penting dan menjadi anjuran pemerintah juga adalah menerapkan pola hidup bersih dan sehat dan ini menjadi hal yang mutlak dijalankan dalam menjalankan aktifitas di masa pandemi covid-19 ini. Pola hidup bersih dan sehat dapat dilakukan dengan berbagai cara yang mudah dilakukan oleh masyarakat. Mulai dari pengaturan pola makan, di mana dengan aktifitas yang kebanyakan dikerjakan dari rumah dengan kata lain Work From Home (WFH), tidak begitu banyak membuang energi untuk mobilitas, maka makanan yang mengandung karbohidrat pun tidak disarankan terlalu banyak, karena dikhawatirkan dapat meningkatkan kadar glukosa dalam darah yang semakin lama semakin menumpuk sehingga justru menimbulkan penyakit baru yaitu diabetes melitus. (Siregar, R., 2020)

Tujuan penerapan hidup bersih dan sehat adalah dalam upaya memutus penyebaran virus covid-19, mencuci tangan dengan sabun dan dengan air yang mengalir sebelum menyentuh bagian tubuh, terutama pancaindra menjadi sangat disarankan. Hal ini merupakan hal yang sulit bagi sebagian besar orang yang harus bepergian keluar rumah, di mana tidak selalu tersedia sabun dan air untuk mencuci tangan. Maka alternatif yang digunakan oleh sebagian besar orang adalah dengan menggunakan antiseptik yang dinamakan dengan hand sanitizer.

Hand sanitizer yang tadinya lebih banyak digunakan di rumah sakit dan sedikit oleh orang-orang tertentu saja, menjadi barang yang paling dibutuhkan dan dicari sejak merebaknya pandemi covid-19. Hal ini disebakan oleh adanya anggapan bahwa kandungan senyawa dalam hand sanitizer dapat membunuh kuman berupa bakteri dan virus. Banyaknya kebutuhan dan pemekaian akan hand sanitizer ini membuat produk ini menjadi sangat mahal dan lebihnya lagi menjadi sangat sulit untuk ditemukan alias langka pada awal maraknya berita tentang pandemi covid-19 ini.

Hal ini menjadi perhatian banyak kalangan, tidak terkecuali Universitas Kristen Indonesia, yang memiliki sembilan fakultas dan 34 program studi yang secara keseluruhan memiliki kewajiban mengimplementasikan tiga dharma perguruan tinggi (pengajaran, penelitian dan pengabdian kepada masyarakat). Sebagai universitas yang memiliki program studi Pendidikan Kimia dan Fakultas Kedokteran tentulah menjadi hal yang tidak sulit bagi Universitas Kristen Indonesia untuk turut berpartisipasi dalam memberikan solusi terhadap permasalahan di masyarakat pada masa pandemi covid-19, terkhusus dalam hal langkanya hand sanitizer.

Melalui penggalangan dana yang dilaksanakan oleh para dosen dengan sukarela, yang kemudian ditambah dengan pembiayaan dana internal perguruan tinggi, selanjutnya oleh dosen Prodi Pendidikan Kimia dan Fakultas Kedokteran UKI sebanyak dua tahap bekerja di Laboratorium Fakultas Kedokteran UKI dalam rangka pembuatan hand sanitizer. 


\section{METODE}

Pelaksanaan kegiatan Pengabdian kepada Masyarakat ini dilakukan secara bertahap, yakni:

\section{A. Pembuatan Hand Sanitizer}

Terdapat beberapa tahapan dalam proses ini, anatara lain:

1. Tahap Persiapan

Tahap persiapan yang dimaksudkan adalah tahapan pengadaan bahanbahan berupa larutan sebagai komposisi hand sanitizer sesuai standar WHO. Pengadaan bahan dilakukan dengan memesan bahanbahan dimaksud kepada vendor atau toko spesial bahan-bahan kimia

2. Tahap Produksi

Tahap produksi dilakukan di laboratorium FK UKI sesuai dengan prosedur dan komposisi sesuai standar WHO.

3. Tahap Pengemasan/Package Pada tahapan ini hand sanitizer yang sudah diproduksi dikemas ke dalam botol dengan ukuran $100 \mathrm{~mL}$

\section{B. Pendistribusian ke Masyarakat}

Hand Sanitizer yang sudah dikemas selanjutnya didistribusi ke beberapa Puskesmas yang terdapat di daerah Kramat Jati, beberapa kelurahan di Kecamatan Kramat Jati Jakarta Timur dan juga masyarakat yang melintas di deapan kampus UKI

\section{HASIL DAN PEMBAHASAN}

\section{Pembuatan Hand Sanitizer}

Hand Sanitizer diproduksi berdasarkan standar World Health Organization (WHO) dengan komposisi: Etanol 96\%, Gliserol 98\%, Hidrogen Peroksida $\left(\mathrm{H}_{2} \mathrm{O}_{2}\right) 3 \%$ dan aquades.
Formula untuk membuat Hand Sanitizer 1 liter adalah sebagai berikut:

- Etanol 96\%, sebanyak $833.3 \mathrm{~mL}$

- Hidrogen Peroksida 3\%, sebanyak $41.7 \mathrm{~mL}$

- Gliserol $98 \%, 14.5 \mathrm{~mL}$

- Air destilasi atau aquades

Adapun prosedur atau langkah yang dilakukan dalam pembuatan hand sanitizer ini adalah sebagai berikut:

1. Etanol terlebih dahulu dimasukkan ke dalam wadah pencampuran dengan volume sesuai kebutuhan

2. Kemudian masukkan $\mathrm{H}_{2} \mathrm{O}_{2}$ dengan takaran sesuai komposisi

3. Lalu tuang gliserol dengan kadar $3 \%$ secara perlahan dan dipastikan untuk tertuang semuanya (mengingat fase gliserol adalah gel)

4. Kemudian dituangkan air destilasi atau aquades

5. Dilakukan pengadukan secara perlahan dan merata.

Dokumentasi proses pembuatan di laboratorium seperti dalam gambar 1 berikut:

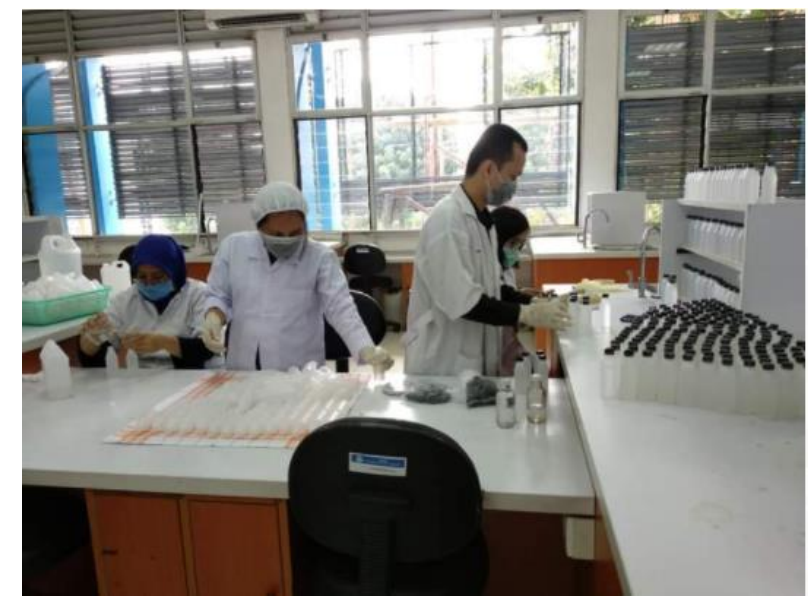

Gambar 1. Foto Pada Saat Proses Pembuatan Hand Sanitizer di Laboratorium FK UKI 
Hasil pencampuran siap dikemas ke dalam botol-botol yang sudah disterilkan terlebih dahulu melalui perendaman dengan air panas dan dikeringkan.

Hand Sanitizer dituang secara perlahan ke dalam botol kemudia langsung ditutup rapat dan ditempatkan di tempat yang aman dan jauh dari api selama 72 jam.

Sebanyak 2000 botol dengan volume $100 \mathrm{~mL}$ diproduksi sebanyak dua tahap dengan dokumentasi seperti pada foto 2 berikut:

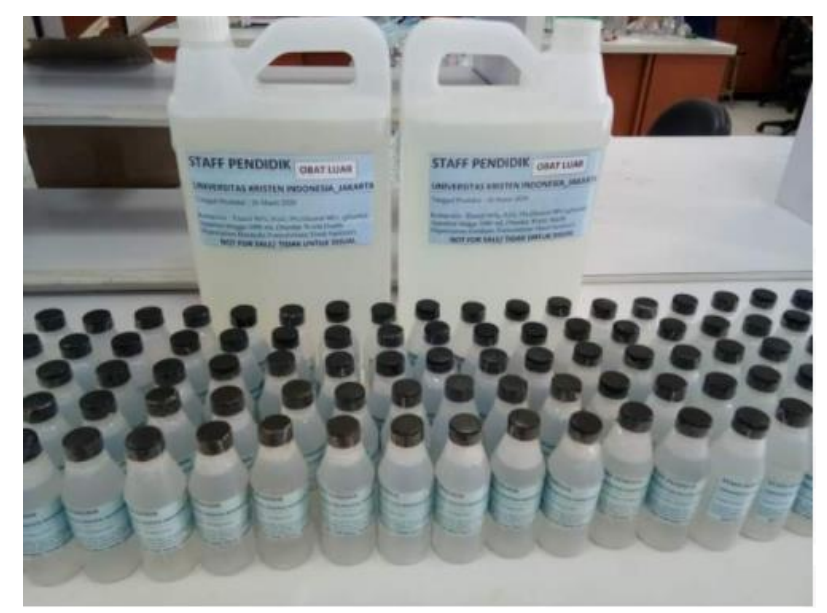

Gambar 2. Foto Hand Sanitizer yang sudah dikemas ke dalam botol

\section{Pendistribusian Hand Sanitizer ke Masyarakat}

Masyarakat yang menjadi mitra sasaran kegiatan pengabdian kepada masyarakat melalui pembagian hand sanitizer ini adalah masyarakat yang berada di daerah di mana UKI berdomisili secara administratif yaitu Jakarta Timur. Terdapat beberapa puskesmas di Jakarta Timur yang disalurkan, seperti puskesmas Cililitan, Puskesmas Kramat Jati, Rumah Sakit UKI dan juga kelurahan-kelurahan, di antaranya adalah Kelurahan Cawang,
Kelurahan Cililitan dan Kelurahan Kebon Pala.

Puskesmas melalui kepala puskesmas mengaku sangat terbantu dengan adanya pendistribusian hand sanitizer dari UKI, disebabkan puskesmas sangat membutuhkan, sementara keberadaannya langka di pasaran. Demikian juga kelurahan-kelurahan melalui kepala lurah masing-masing juga mengucapkan rasa terimakasih yang sangat besar kepada UKI karena dalam masa-masa sulit seperti ini UKI dengan cepat dan tanggap membantu pemerintah, sehingga beberapa kendala di masyarakat dapat diselesaikan, termasuk dalam hal pengadaan hand sanitizer.

Hal ini disampaikan sangat membantu mengingat di tiap-tiap lorong atau gang diterapkan sistem tutup akses atau diijinkan masuk jika sudah mencuci tangan atau menggunakan hand sanitizer.

Dokumentasi penyerahan hand sanitizer ke puskesmas dan kelurahan seperti foto berikut.

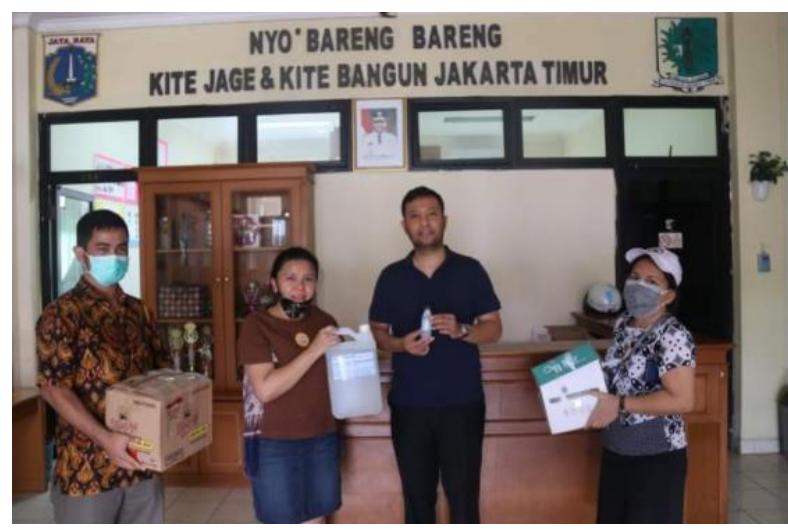




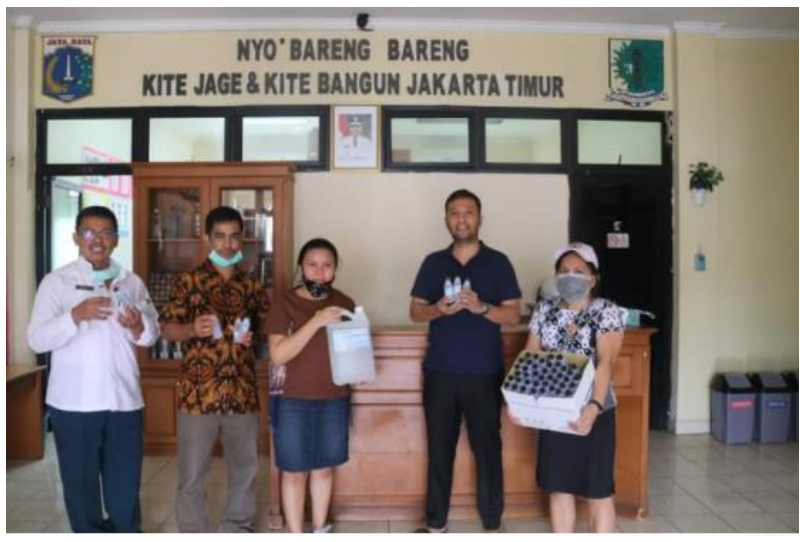

Gambar 3. Foto penyerahan Hand Sanitizer ke Kelurahan Cawang

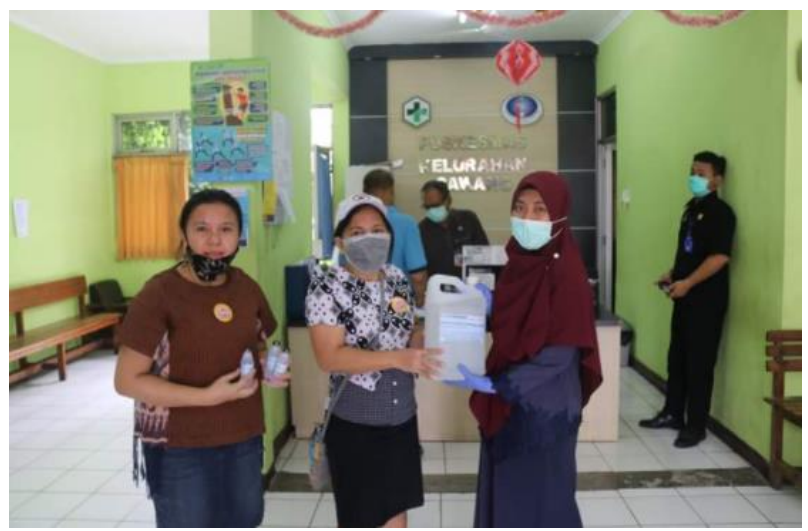

Gambar 4. Foto penyerahan Hand Sanitizer ke Puskesmas Cililitan
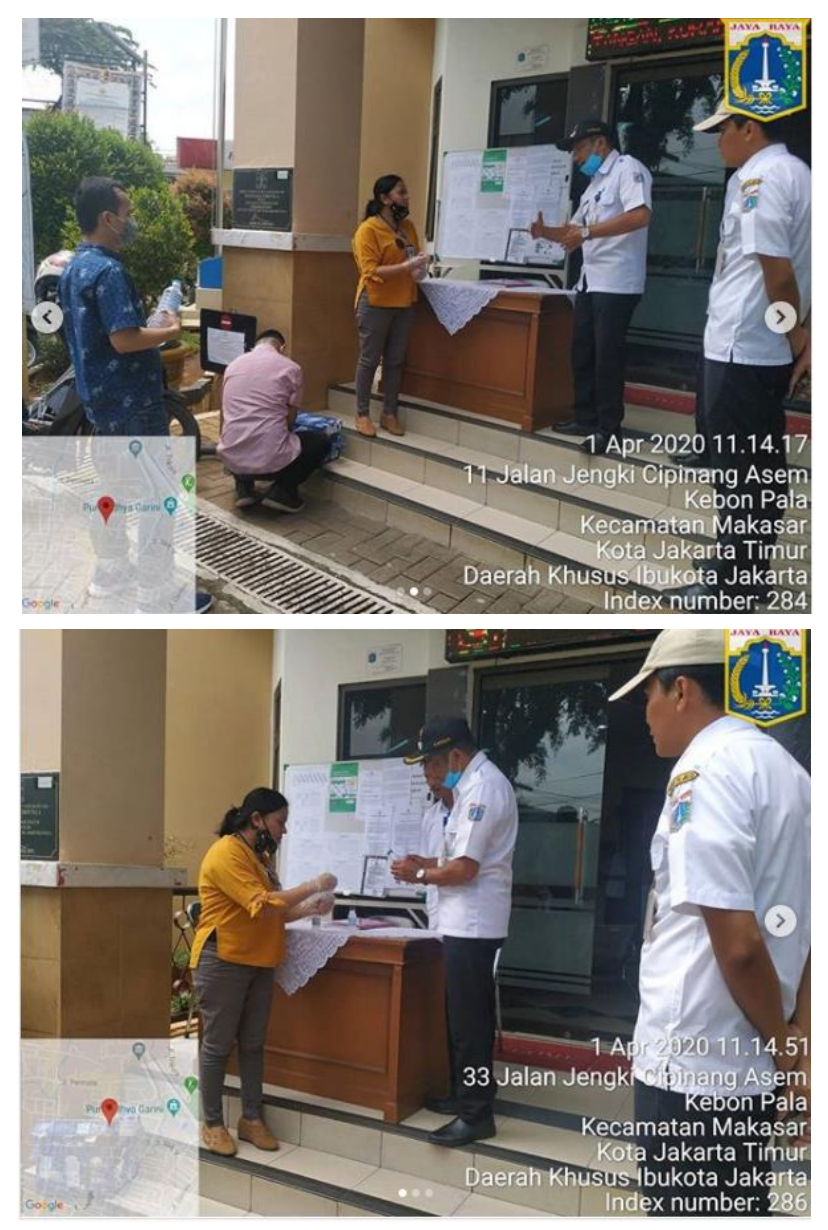

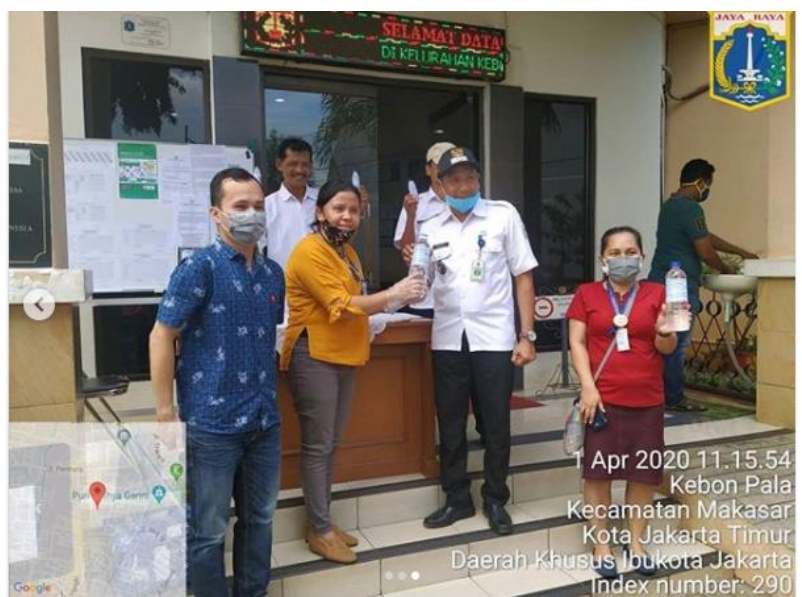

Gambar 5. Foto Penyerahan Hand Sanitizer ke Kelurahan Kebon Pala

Selain distribusi ke puskesmas dan kelurahan, Tim PkM UKI juga membagikan hand sanitizer tersebut kepada masyarakat yang beristirahat maupun yang melintas di pinggir jalan depan kampus UKI, seperti driver ojek online, driver angkutan kota yang melintas, dan juga beberapa pedagang warung yang berada di sekitaran kampus UKI. Mereka menyampaikan rasa terimakasih dan mengaku sangat terbantu dengan adanya pembagian hand sanitizer, bahkan sebagian masyarakat ada yang mengaku baru pertama kali menggunakan hand sanitizer semenjak pandemi covid-19.

\section{SIMPULAN}

Pada masa pandemi covid-19 UKI secara aktif dan partisipatif dalam membantu masyarakat. Melalui kegiatan pembuatan dan pendistribusian Hand Sanitizer yang merupakan kebutuhan masyarakat dalam upaya menerapkan pola hidup bersih dan sehat menjadikan masyarakat secara khusus di daerah Jakarta Timur menjadi terbantu. Terlebih lagi Puskesmas yang dalam 
kegiatan sehari-hari berhadapan dengan masyarakat umum dalam hal ini pasien, sehingga sangat membutuhkan keberadaan hand sanitizer ini sebagai penambah antiseptik yang biasanya disediakan bagi para pengunjung puskesmas ataupun pasien yang datang dan pergi. Dalam menghadapi pandemi, sinergitas dari semua stake holder menjadi hal yang utama untuk dilaksanakan, sehingga beban yang berat dapat dirasakan lebih ringan dan terseelsaikan dengan baik.

\section{DAFTAR PUSTAKA}

Siregar, R. A., Amahorseja, A. R., Adriani, A., \& Andriana, J. (2020). PROFIL KADAR GLUKOSA DARAH SEWAKTU, KADAR ASAM URAT DAN KADAR CHOLESTEROL PADA MASYARAKAT DI DESA ERETAN WETAN INDRAMAYU KABUPATEN FEBRUARI PERIODE ComunitÃ Servizio: Jurnal Terkait Kegiatan Pengabdian kepada Masyarakat, terkhusus bidang Teknologi, Kewirausahaan dan Sosial Kemasyarakatan, 2(1), 291300.

Nadeak, B., Juwita, C. P., Sormin, E., \& Naibaho, L. (2020). Hubungan kemampuan berpikir kritis mahasiswa dengan penggunaan media sosial terhadap capaian pembelajaran pada masa pandemi Covid-19. Jurnal Konseling dan Pendidikan, 8(2), 98-104.

Nadeak, B., Deliviana, E., Sormin, E., Naibaho, L., \& Juwita, C. P. (2019).
Pembinaan Ketahanan Pernikahan dan Keharmonisan Keluarga Dengan Tema "The Family Relationship and Intimacy. Jurnal ComunitÃ Servizio: Jurnal Terkait Kegiatan Pengabdian kepada Masyarakat, terkhusus bidang Teknologi, Kewirausahaan dan Sosial Kemasyarakatan, 1(2), 179185.

Nadeak, B., Sormin, E., Naibaho, L., \& Deliviana, E. (2020). Sexuality in Education Begins in The Home (Pendidikan Seksual Berawal Dalam Keluarga). Jurnal Comunita Servizio, 2(1), 254-264.

Arifudin, O., Hidana, R., Julius, A., Doho, D. B., Sormin, E., Ghazali, A., ... \& Zuwirna, Z. (2020). PSIKOLOGI PENDIDIKAN (TINJAUAN TEORI DAN PRAKTIS).

Sormin, E., Napitupulu, R., Andrianawati, N. S., Gunawan, R., Ernawati, R., \& Wigunawati, E. (2019). PENDAMPINGAN PENGELOLAAN DAN PEMBINAAN KELOMPOK BINA KELUARGA LANSIA (BKL) MELALUI KEGIATAN PENGABDIAN PADA MASYARAKAT DOSEN DAN MAHASISWA DI WILAYAH JAKARTA TIMUR. JURNAL ComunitÃ Servizio: Jurnal Terkait Kegiatan Pengabdian kepada Masyarakat, terkhusus bidang Teknologi, Kewirausahaan dan Sosial Kemasyarakatan, 1(2), 198207. 